University of Tennessee Law

Legal Scholarship Repository: A Service of the Joel A. Katz Library

UTK Law Faculty Publications

2019

Regulatory Policy in the Trump Era and its Impact on Innovation

Brian Krumm

Follow this and additional works at: https://ir.law.utk.edu/utklaw_facpubs

Part of the Law Commons 


\section{T THE UNIYERITY OF TENNESSEE KNOXVILLE}

COLLEGE OF LAW
Legal Studies

Research Paper Series

\author{
Research Paper \#383 \\ September 2019
}

\title{
Regulatory Policy in the Trump Era and its Impact on Innovation
}

\author{
Brian Kingsley Krumm
}

Mercer Law Review Vol. 70 (2019)

This paper may be downloaded without charge

from the Social Science Research Network Electronic library at:

http://ssrn.com/abstract $=\mathbf{3 4 0 4 2 0 5}$

Learn more about the University of Tennessee College of Law:

law.utk.edu 


\section{Regulatory Policy in the Trump Era and its Impact on Innovation}

\section{By Brian Kingsley Krumm*}

\section{INTRODUCTION}

Since the mid-nineteenth century, the strength of the United States economy has been driven largely by the ability of Americans to innovate. ${ }^{1}$ Beyond macro-economic growth, innovation increases per capita income and improves standards of living and quality of life. ${ }^{2}$ Furthermore, innovation begets innovation. As companies within a market innovate, pressure is placed on their competitors to innovate as well in order to protect profitability and market share. For most of the last half century, the United States boasted the strongest intellectual property system $^{3}$ and was called home by the most innovative companies in the world. ${ }^{4}$ However, in the last five years, the United

*Associate Professor of Law, The University of Tennessee College of Law, State University of New York at Oswego (B.A., 1977); Maxwell School of Citizenship and Public Affairs, Syracuse University (M.P.A., 1980); University of Tennessee College of Law (J.D., 1992); Anderson Center for Entrepreneurship and Innovation Research Council, Haslam School of Business.

1. Nat'L Research Council, Rising to the Challenge: United States InNovation Policy for the Global Economy 201 (Charles W. Wessner \& Alan Wm. Wolff eds., 2012).

2. David Ahlstrom, Innovation and Growth: How Business Contributes to Society, 24 ACAd. MGMt. Perspectives 11, 11-12 (2010). In this article, Ahlstrom challenges famed economist Milton Freidman's contention that business's sole purpose is to generate profits for shareholders. Id. Instead, he argues that the main goal of business is to develop new and innovative products that generate growth and deliver important benefits to an increasingly wide range of the world's population. $I d$.

3. The United States was ranked number one for intellectual property protection and strength until 2016. Gene Quinn, U.S. Falls from 1st to 10th in Patent System Strength, INVENTORS DiG. (May 15, 2017), https://www.inventorsdigest.com/articles/u-sfalls-1st-10th-patent-system-strength/.

4. In 2013, the United States was home to $75 \%$ of global unicorn start-ups. Ellen Sheng, Silicon Valley Is Fighting a Brain-Drain War with Trump That It May Lose, CNBC (Apr. 9, 2018), https://www.cnbc.com/2018/04/09/trumps-war-on-immigrationcausing-silicon-valley-brain-drain.html. 
States has witnessed an unanticipated decline in innovative supremacy. ${ }^{5}$ In 2017 , the United States fell to tenth in the world for net impact on global innovation ${ }^{6}$ and the United States' share of global tech unicorn start-ups ${ }^{7}$ has fallen to $41 \% .{ }^{8}$ This alarming decrease in innovative supremacy has fueled a groundswell of opinions on how to resolve this downward trend.

Of the potential causes for the United States' declining innovative health, some point to federal government regulations as the major culprit. However, government regulations can have both positive and negative effects on the innovative process. Regulation directly affects the innovative process, and in turn, innovation and technical change can have a significant effect on regulation. To be successful, regulatory reform must take into account the linkages between regulation and innovation. The need for recognizing these dynamic linkages has become even more important under the Trump Administration. During his first days in office, President Trump informed business leaders that he planned to cut government regulations by at least $75 \% .^{9}$ This was soon followed by his issuance of Executive Order 13771,10 more colloquially known as his "2-for-1" order, which requires federal agencies to eliminate two regulations for every new regulation that is issued. ${ }^{11}$ While touted as a measure to reduce the regulatory burdens on the American people, thus promoting economic growth and innovation, the consequences of his policies, taken as a whole, may not achieve such results. This Article explores the potential effect the Trump Administration's regulatory agenda may have on innovation in the United States.

Part II of this Article will discuss the importance of innovation as the key component to the long-term well-being of the American economy. Part III analyzes the administration's regulatory reform agenda and its potential for achieving its desired results. Part IV explores the

5. Id.

6. Quinn, supra note 3 (noting that this time the United States was not ranked number one in the U.S. Chamber of Commerce's Global IP Index for the category).

7. Note that a unicorn start-up is a privately held start-up company that is valued at one billion or more. Zoe Bernard, 16 Startups That This Year Became Worth Billions, BUS. INSIDER (Apr. 12, 2018), http://www.businessinsider.com/startups-that-becameunicorns-in-2018-by-crossing-1-billion-valuation-list-2018-4.

8. Sheng, supra note 4.

9. Chris Arnold, President Trump to Cut Regulations by '75 Percent'-How Real Is That?, NPR (Jan. 24, 2017), https://www.npr.org/2017/01/24/511341779/president-trumpto-cut-regulations-by-75-percent-how-real-is-that.

10. Exec. Order No. 13771, 82 Fed. Reg. 9339 (Feb. 3, 2017).

11. Id. 
administration's proposed budget cuts to agency research and development programs and the resulting consequences that such a policy could have on the country's innovation ecosystem. Part V focuses on the future of the United States Patent and Trademark Office, including the selection of Andrei Iancu as director and the initiatives that he has proposed to improve the intellectual property management system. Part VI examines the administration's isolationist policies and restrictions on foreign investment in the United States as a "regulation" that impacts the advancement of innovation. Part VII will conclude by proposing that, absent a comprehensive, coordinated strategy, attempts to correct perceived market failures due to overregulation may have a deleterious effect on innovation, and consequently on the economy.

\section{INNOVATION AS A KEY COMPONENT TO THE LONG-TERM ECONOMIC AND SOCIAL PROSPERITY}

The justification for government deregulation can be found in Free Market Economic Theory, which posits that the prices people pay for goods and services should be agreed to by buyers and sellers with little or no control by the government. ${ }^{12}$ Milton Friedman, a free market economist, took this theory one step further through the Stockholder Theory, which advances the proposition that the only social responsibility a corporation has is to increase profits for its shareholders, as long as it does not engage in deception or fraud. ${ }^{13}$ However, data over the past several decades shows that, while profits matter, the most successful firms are those that bring new technology and innovation to market. ${ }^{14}$ Innovation economists believe that what primarily drives economic growth in our knowledge-based economy is not capital accumulation, but developing innovative policies and systems that create innovative environments. ${ }^{15}$ Innovation economist Professor David Ahlstrom contends that "the main goal of business is to develop new and innovative goods and services that generate economic growth while delivering important benefits to society." 16

A classic example of how these economic theories can play out in practice can be demonstrated through the Eastman Kodak experience.

12. What are Free Market Economies?, INVESTOPEDIA, https://www.investopedia.com/ video/play/free-market-economy/ (last visited Dec. 9, 2018).

13. Milton Friedman, A Friednzan Doctrine, N.Y. TIMEs (Sept. 13, 1970), https://www. nytimes.com/1970/09/13/archives/a-friedman-doctrine-the-social-responsibility-of-business -is-to.html.

14. Ahlstrom, supra note 2 , at 10 .

15. Id.

16. Id. 
In 1975, a Kodak engineer invented the first digital camera. ${ }^{17}$ At the time, Kodak was the dominant brand in the photography business, and management decided not to commercialize the invention as it was thought that it would cannibalize its film businesses. ${ }^{18}$ In 1981, Sony introduced the first electronic camera to market, which later disrupted the chemical-based film and paper business that fueled Kodak company profits for decades. ${ }^{19}$ In 2012, Kodak filed for bankruptcy. ${ }^{20}$ The company's focus on short-term profitability at the expense of adopting new technology contributed to the company's demise. ${ }^{21}$

While the economic power of a nation was once determined by the strength of its labor capital, now economic power is measured through the strength of a nation's intellectual property system. The literature relating to research on innovation has been growing in recent years, and it has been demonstrated both theoretically and empirically that innovation is the main driver of long-run economic growth. ${ }^{22}$ As a U.S. Department of Commerce White Paper explains,

Today, as an empirical matter, we have strong evidence that the introduction of both new products and new processes is responsible for the lion's share of the $3.4 \%$ average annual growth rate the U.S. has enjoyed since World War II. While 0.9 percentage point of this annual growth has come from expansion of the labor force, the remaining 2.5 percentage points have come from factors intimately linked to innovation-capital investment (1.1\%) and increased efficiency (1.4\%). In other words, factors linked to innovation are responsible for almost three-quarters of the Nation's post-WW II growth rate. ${ }^{23}$

17. James Estrin, Kodak's First Digital Moment, N.Y. TIMES (Aug. 12, 2015), https://lens.blogs.nytimes.com/2015/08/12/kodaks-first-digital-moment/.

18. Id.

19. Chunka Mui, How Kodak Failed, ForBes (Jan. 19, 2012), https://www.forbes. com/sites/chunkamui/2012/01/18/how-kodak-failed/\#718313606f27.

20. $I d$.

21. $I d$.

22. See generally Christopher FreEman \& LuC Soete, The Economics of INDUSTRIAL INNOVATION 1-26 (3d ed. 1997) (reviewing the substantial economic literature on this point).

23. ARti Rai ET AL., PATENT Reform: Unleashing InNOVAtion, Promoting Economic Growth \& Producing High-Paying Jobs 2 (2010) (citing Dale W. Jorgenson, Mun S. Ho, Jon D. Samuels \& Kevin J. Stiroh, Industry Origins of the American Productivity Resurgence, 19 ECON. SYS. RES. 229 (2007)). In the economics literature, "efficiency" is often referred to as total factor productivity. See also Michael J. Boskin \& Lawrence J. Lau, Generalized Solow-Neutral Technical Progress and Postwar Economic Growth (Nat'l Bureau of Econ. Research, Working Paper No. 8023, 2000) (finding that 
Building upon this understanding, it is critical that our nation's deregulation efforts focus not solely on its effect on corporate profitability, but its long-term effect on innovation.

\section{The Potential IMPACT OF DEREGULATION}

Following in the footsteps of prior administrations, ${ }^{24}$ the White House has made regulatory reform one of the pillars of the president's policy agenda. Within his first week in office, President Trump issued Executive Order 13771, which addressed the massiveness of the existing regulatory state. ${ }^{25}$ Dubbed the "two-for-one" policy, Executive Order 13771 requires that "for every one new regulation issued, at least two prior regulations be identified for elimination." 26 The objective of the two-for-one policy is to cut through the regulatory red tape that is constraining both large and small businesses in the United States, thus stimulating economic growth and job creation. ${ }^{27}$ Under Executive Order 13771, regulatory requirements are suggestive rather than compulsory for independent agencies. ${ }^{28}$

Establishing an annual regulatory budget, Executive Order 13771 requires "that the total incremental cost of all new regulations, including repealed regulations, to be finalized this year shall be no

physical capital and technical progress contributed $75 \%$ of the U.S. growth between 1960 and 1997).

24. Addressing overregulation is hardly a novel concept for American presidents. Since the Ford Administration, regulatory reform has been one of the few policy areas that has transcended party lines. With Executive Order 12044, the Carter Administration formally launched regulatory oversight by the White House. Under the Reagan Administration, Executive Order 12291 was the first to implement a balance system of benefits and costs to society. The Clinton Administration would alter the balance system established under Reagan to require benefits only to justify cost, rather than outweigh. The tradition of addressing regulatory reform would continue in both the Bush and Obama Administrations. Ted Gayer et AL., Evaluating the Trump Administration's REGULATORY REFORM PROGRAM 5 (2017), https://www.brookings.edu/wp-content /uploads/2017/10/evaluatingtrumpregreform_gayerlitanwallach_102017.pdf.

25. Id. at 3; Bourree Lam, Trump's “Two-for-One" Regulation Executive Order, THE ATLANTIC (Jan. 30, 2017), https://www.theatlantic.com/business/archive/2017/01/trumpsregulation-eo/515007/.

26. Exec. Order No. 13771, supra note 10.

27. Lam, supra note 25 (The Trump Administration has long taken the stance that "overregulation is hampering America's economic growth," including job growth).

28. Memorandum from Dominic J. Mancini, Acting Admin., Office of Info. \& Regulatory Affairs, to Regulatory Policy Officers at Exec. Dep'ts \& Agencies, Guidance on Regulatory Reform Accountability Under Executive Order 13777, Titled "Enforcing the Regulatory Reform Agenda” (Apr. 28, 2017), https://www.whitehouse.gov/sites/whitehouse.gov/files/omb/memoranda/2017/M-17-23.pdf. 
greater than zero." 29 The regulatory budget is considered to be an attempt to require agencies to prioritize regulations by establishing a cost cap for the implementation and management of regulations. ${ }^{30}$ Since the 1970s, economists and policy makers have discussed the need for further acknowledgment of the economic impact of regulation on the United States economy, including the potential benefits of establishing a regulatory budget. ${ }^{31}$ The use of a regulatory budget in tandem with a cost-benefit analysis has been identified as a potentially superior method to counter overregulation. ${ }^{32}$ While the addition $^{33}$ of the regulatory budget is not unheard of in American politics, the lack of congressional involvement in the setting of the regulatory budget is novel. ${ }^{34}$ In developing its regulatory budget, the White House did not involve Congress in the initial decision-making process. ${ }^{35}$ This lack of congressional involvement in the early stages of the budget setting

29. Exec. Order No. 13771, supra note 10. According to the Two-for-One Status Report, the 2017 zero net cost allowance was met within the first eight months of administration. OfF. INFo. \& REg. AfF., REgulatory REForm: TwO-For-OnE STATUS $\begin{array}{lllll}\text { REPORT AND COST REGULATORY } & \text { CAPS }\end{array}$ https://www.reginfo.gov/public/pdf/eo13771/FINAL_TOPLINE_All_20171207.pdf.

30. GAYER ET AL., supra note 24, at 5-7 (analogizing the regulatory budget to the cap-and-trade mechanism established to reduce carbon emissions). The point of the cap is to use a price mechanism so that target reform is obtained at the least possible cost. Id. at 6.

31. In 1978, Robert Crandell identified the regulatory budget as the "most practical" manner to force regulators to understand the cost of their actions. Id. In 1980, the Council of Economic Advisers both cautioned the potential pitfalls of regulatory budget and acknowledged the need of tools, such as the regulatory budget, to deal with the "impact of regulations on the economy." Id.

32. Id.

33. "Regulations are meant to address market failures." Id. at 5 . In theory, agencies should be able to "identify the existence of market failures, evaluate the options for addressing them, analyze the benefits and costs associated with each option... and choose the approach that maximizes net social benefits." Id. Traditionally, regulatory reform policy has been guided by the economic principle "that optimal policy ... is achieved by maximizing net social benefits (the difference between total benefits and total costs to society)." Id. at 4 . This economic balancing board has been used since the Carter Administration, with some adjustments by both the Clinton and Obama Administrations to include distributive and equitable considerations. Id. However, all things considered, this manner of addressing market failure operates best in a vacuum. "[T]he real-world political economy of the regulatory policymaking process deviates from the conceptual idea of maximizing net social benefits, leading to an inefficiently high burden from regulations." Id. at 5 .

34. Earlier proposals to implement a regulatory budget have included a strong role for Congress to play, such as an approval and implementation process similar to other legislative actions. Id. at 7 .

35. Id. 
process is novel from a historical perspective and will likely have a detrimental effect on the overall success of the administration's regulatory budget.

How the Trump Administration's strong deregulatory stance will affect innovation is still largely undetermined, but there is promise that deregulation may have a positive impact. Arguably, regulatory reform can promote innovation and economic growth by allowing individuals and businesses more freedom to focus their efforts on inventiveness, rather than navigating the overwhelming regulatory road to compliance. ${ }^{36}$ By scaling back regulatory requirements, the administration is increasing business confidence throughout the country. ${ }^{37}$ While there is no proven correlation between decreased regulation and increased economic growth, there is a demonstrated connection between an increase in business confidence and positive economic growth. ${ }^{38}$ From a corporate management perspective, it appears that the simple reassurance that there will not be additional increases in regulatory costs is enough to ensure optimism. ${ }^{39}$ With this being said, there are several factors that may contribute to the increased confidence of the business community that are not related to the regulatory reform efforts, including decreased unemployment rates and the fact that, for the first time since the 2007-2008 recession, all of the world's major economies are growing.40 However, low unemployment rates can be the result of a number of factors, including increased federal spending. Tax reform has also been a major factor in the improvement of business confidence.41 In addition, the fact that there is growth present in all major economies suggests that there are

36. Neomi Rao, Advancing Responsible Regulatory Reform: The Deregulatory Agenda, OfF. MGMT. \& BudGET (May 9, 2018), https://www.whitehouse.gov/articles/advancingresponsible-regulatory-reform-deregulatory-agenda/.

37. Binyamin Appelbaum \& Jim Tankersley, The Trump Effect: Business, Anticipating Less Regulation, Loosens Purse Strings, N.Y. Times (Jan. 1, 2018), https: //www.nytimes.com/2018/01/01/us/politics/trump-businesses-regulation-economicgrowth.html.

38. $I d$.

39. An Assessment of the White House's Progress on Deregulation, ECONOMIST (Oct. 14, 2017), https://www.economist.com/business/2017/10/14/an-assessment-of-the-whitehouses-progress-on-deregulation.

40. Low unemployment rates are often connected to increased spending among consumers. Economic growth in all major economies suggests that there is more contributing to business confidence than regulation reform. Appelbaum \& Tankersley, supra note 37.

41. Sean Hackbarth, Tax Reform Boosts Middle Market Business Confidence to an All-Time High, U.S. CHAMBER COM. (Mar. 23, 2018), https://www.uschamber.com/ series/above-the-fold/tax-reform-boosts-middle-market-business-confidence-all-time-high. 
more factors contributing to business confidence than regulation reform alone.

Other countries have embarked on similar deregulatory endeavors with dramatic success. In 2001, British Columbia enacted a plan to reduce the Canadian province's regulatory burden by one third in three years, which required each ministry to match any new regulatory requirement with the elimination of two requirements. ${ }^{42}$ Exceeding its goal and achieving a $40 \%$ reduction in regulatory requirements, British Columbia then imposed a regulatory cap that would be extended three times and would reach a total reduction of $49 \%$ for regulatory requirements in 2017.43 The dramatic success of British Columbia's regulatory reform inspired the Canadian government to adopt a national regulatory reform initiative in 2012 that required a "one-for-one" implementation and elimination plan for regulations. ${ }^{44}$ The United Kingdom also adopted a "one-in, one-out" regulatory reform plan in 2011 (later increased to a "one-in, two-out" rule in 2013, and again increased to a "one-in, three-out" rule in 2016). ${ }^{45}$ The United Kingdom has focused its regulatory reform on a net-cost basis, rather than a regulatory elimination platform; the regulatory reform initiative parallels the reform agenda of the administration with its absence of a social welfare component in measurement. ${ }^{46}$ In both circumstances, the implementation and elimination methodology has been seemingly successful in reducing regulatory cost and in creating a more efficient regulatory system. ${ }^{47}$ Therefore, it is reasonable to expect that the administration's deregulation agenda will have a positive impact on the United States economy and innovation.

However, there remains serious uncertainty about whether this strong deregulatory stance will prove fruitful in the face of numerous obstacles. Perhaps the most serious obstacle to the success of the two-for-one policy is the overlapping requirements of the Administrative Procedure Act (APA). ${ }^{48}$ Under the APA, standing to

42. GAYER ET AL., supra note 24 , at 7 .

43. $I d$.

44. Id. at 8 .

45. $I d$.

46. $I d$.

47. $I d$.

48. Pub. L. No. 79-404, 60 Stat. 237 (1946) (codified at 5 U.S.C. $§ 500$ (2018)). Born as a result of a politically contentious time period, the Administrative Procedure Act addresses six aspects (or requirements) of federal administrative agencies: (1) publication of agency organization, function, and procedure; (2) including an opportunity for public participation in rulemaking proceedings; (3) conduct of rulemaking and adjudicatory proceedings; (4) judicial review of agency action; (5) independence of examiners in agency 
bring suit against the government for failure to comply is fairly broad. ${ }^{49}$ Procedurally, each agency will have to follow the formal notice and public comment set forth by the APA for every regulation proposed, revised, or repealed in compliance with Executive Order 13771.50 Further, under the APA requirements, the deregulatory actions taken by the agencies must not appear to be arbitrary and capricious, ${ }^{51}$ and therefore, the administration must maintain an evidentiary record that will justify the shift in policy when revising or repealing regulations. ${ }^{52}$ In addition, there is a practical obstacle to the implementation of the deregulation scheme. Measurement issues will likely result in greater inconsistency in regulatory implementation, revision, and revocation across the different executive agencies. ${ }^{53}$ Since different agencies have different internal methods for measuring the success of a regulation and because there is no consistent metric set by the administration, the regulatory system at large has little guidance for determining the effectiveness of a regulation across the board. The lack of a consistent metric may slow the deregulation process and defer the accurate measurement of deregulation's impact. As a result, the true impact of the deregulation process on innovation will likely remain unclear for the foreseeable future.

hearings; and (6) additional ancillary procedural points. Ralph F. Fuchs, Attorney General's Manual on the Administrative Procedure Act, Prepared by the United States Department of Justice; The Federal Administrative Procedure Act and the Administrative Agencies, Vol. VII of the New York University School of Law Institute Proceedings, 23 IND. L.J. 362 (1948).

49. Under 5 U.S.C. $§ 702$, persons who suffer a "legal wrong because of agency action" or are "adversely affected or aggrieved by agency action within the meaning of a relevant statute" have standing to receive judicial review of the agency's action. 5 U.S.C. $\S 702$ (2018). There are four elements that must be proven to gain judicial review: (1) injury in fact; (2) causation; (3) redressability; and (4) zone of interest. See Lujan v. Defs. of Wildlife, 504 U.S. 555, 560-61 (1992); Ass'n of Data Processing Serv. Orgs., Inc. v. Camp, 397 U.S. 150 (1970).

50. Marc E. Williams \& Anna C. Majestro, Regulation Through Deregulation: Trump's First Year in Office, 13(1) IN-House DEF. Q. 36 (2018); GAYER ET AL., supra note 24 , at 13.

51. Motor Vehicle Mfrs. Ass'n v. State Farm Mut. Auto. Ins. Co., 463 U.S. 29 (1983). In Motor Vehicle Manufacturers' Ass'n v. State Farm, the Supreme Court of the United States explicitly held that "revocations or rescissions must pass the same 'arbitrary and capricious' test required for all new rules." GAYER ET AL., supra note 24, at 12 (citing Motor Vehicle Mfrs. Ass'n, 463 U.S. at 44).

52. GAYER ET AL., supra note 24, at 12 .

53. Id. at $14-15$. 


\section{Regulating Through the Federal Budget AND ITS IMPACT ON INNOVATION}

One of the principle variables for determining how innovative the United States will be in the future is the national budget. ${ }^{54}$ How the federal budget is allocated among the various agencies may be considered a form of administrative regulation. These budgetary allocations either foster or discourage innovation depending on whether the budget is cut or increased. ${ }^{55}$ By providing increased funding to an agency, the administration incentivizes growth and development within that agency. ${ }^{56}$ Correspondingly, when an agency's funding is reduced, it negatively affects innovation by decreasing the resources available to foster growth and development both within that agency, as well as through outside researchers receiving agency grants. Reducing funding for an agency may also have a negative effect on innovation by reducing the pressure placed on businesses subjected to the regulations. Budget cuts may have the effect of reducing regulatory enforcement, therefore removing the incentive for companies to innovate. In the absence of federal regulations, certain innovations would not occur. For example, if companies were not required to comply with emissions standards, it is unlikely that investment would have been made in scrubber technologies to combat industrial exhaust. By reducing the pressure to

54. Pricewaterhouse COOPERS, GOVERnMEnT'S MANY ROLES IN Fostering INNOVATION 7 (2010), https://www.pwc.com/gx/en/technology/pdf/how-governments-fosterinnovation.pdf (stating that "[s]ustained success in fostering innovation and enhancing private markets, by encouraging the creation of new participants, always hinges on linking funds to performance.”); see also CONG. BUdGET OfFICE, FEDERAL Policies AND INNOVATION 9 (2014), https://www.cbo.gov/sites/default/files/113th-congress-2013-2014/ reports/49487-Innovation.pdf ("The federal government promotes innovation directly by funding research and development and education, and indirectly by encouraging private investment in $R \& D$ and other innovative activity through tax preferences and loans and loan guarantees.”).

55. Pricewaterhouse CoOpers, supra note 54, at 9 ("Direct subsidies [funding] often target certain industries, either because they are seen as strategically important (as for defense purposes) or because the government believes it can foster growth in a particular sector.... This ensures that resources from the state budget are invested in the best projects within the topics defined by the political authorities.").

56. ORG. FOR ECON. Co-Operation \& Dev., InNOvation AND Growth: Rationale FOR AN INNOVATION STRATEGY 5 (2007), https://www.oecd.org/sti/inno/39374789.pdf ("Public investment in science and basic research can play an important role in developing [information and communication technologies] and, hence, in enabling further innovation."). 
comply with specific regulations, the government is removing the incentive to develop new technology to address compliance issues. ${ }^{57}$

Historically, budgetary expenditures for the national defense have spurred the greatest advancements in technological innovation, which in turn resulted in economic expansion. With the advent of World War II, the federal government drastically increased the budget for the national defense. ${ }^{58}$ Most of the national budget came through the Department of Defense (DOD), where the research was focused predominately on defense technologies. ${ }^{59}$ These expenditures produced innovation in weaponry, biological sciences, ${ }^{60}$ and nuclear science, ${ }^{61}$ among many other fields. War time necessity served as a trigger for innovation in areas that had been stagnant during the time of relative isolation following World War I and the Great Depression. For fiscal year 2019, the Trump Administration has advanced a $\$ 716$ billion defense budget, 62 an $\$ 82$ billion increase from fiscal year 2017.63 Further, the DOD budget for fiscal year 2019 represents $10 \%$ real

57. Setting Emissions Standards Based on Technology Performance, U.S. ENVTL. PROTECTION AGENCY, https://www.epa.gov/clean-air-act-overview/setting-emissions-stand ards-based-technology-performance (last visited Jan. 14, 2019).

58. Financing InNovation in the United States, 1870 to the Present, at 21-22 (Naomi R. Lamoreaux \& Kenneth L. Sokoloff eds., 2007).

59. See id. at 21. "Through most of the 1953-2005 period, more than 50 percent of th[e] federal R\&D budget was devoted for defense purposes." Kira R. Fabrizio \& David C. Mowery, The Federal Role in Financing Major Innovations: Information Technology During the Postwar Period, in Financing InNOvation, supra note 58, at 283.

60. During World War II, the United States Army organized a commission to develop the first flu vaccine in anticipation of the United States joining the war. See Kendall Hoyt, More Soldiers Used to Die of Disease than Battle Injuries-So the US Army Developed the Flu Vaccine, BUs. INSIDER (Feb. 4, 2018), http://www.businessinsider.com/how-world-warii-and-the-us-army-spurred-vaccine-innovation-2018-2. Further, World War II resulted in an expansion in the scope of the military's work in vaccines. Id. This expansion would spur new research initiatives that focused on tropical diseases, bacterial meningitis, neurotropic diseases, among numerous other diseases. $I d$.

61. Arguably, the most prolific innovation developed in the United States as a result of World War II was the atomic bomb. The scientific research that went into the development of the weapon later resulted in the advancements in civilian applications for energy and medicine. ADVISORY COMM. ON HUMAN RADIATION EXPERIMENTS, FINAL REPORT (1995), https://www.osti.gov/opennet/servlets/purl/120931/120931.pdf.

62. The budget of $\$ 716$ billion represents $\$ 686$ Billion to the Department of Defense and $\$ 30$ billion to address other national defense. U.S. DEP'T OF DEF., FiSCAL YEAR 2019 BUDGET REQUEST 3 (2018), https://comptroller.defense.gov/Portals/45/Documents/def budget/fy2019/FY2019_Budget_Request.pdf.

63. Jeff Stein, U.S. Military Budget Inches Closer to $\$ 1$ Trillion Mark, as Concerns over Federal Deficit Grow, WASH. Post (June 19, 2018), https://www.washingtonpost.com/ news/wonk/wp/2018/06/19/u-s-military-budget-inches-closer-to-1-trillion-mark-as-concerns -over-federal-deficit-grow/?noredirect=on\&utm_term=.6230cac07013. 
growth over the DOD's current continuing resolution levels for 2018. ${ }^{64}$ This is the largest military budget in recent history. ${ }^{65}$ If we rely on historical precedent, the increase in budget should produce advancements in military technology and the potential for widespread defense related innovation is pronounced.

However, the White House has identified a number of agencies for drastic budget cuts that, without the interference of Congress, would have potentially negative effects on innovation. The administration's first budget proposal sent shockwaves through the science, health, and technology fields as the White House budget proposed steep budget cuts for the National Institutes of Health (NIH) and the National Science Foundation (NSF). ${ }^{66}$ Ultimately, Congress rejected the steep cuts to the NIH and NSF in the 2018 budget and chose to increase the NIH's budget to $\$ 36.1$ billion. 67 The fiscal year 2019 budget proposed by the administration also included major reductions in research and development funding. ${ }^{68}$ At the last moment, Congress passed a $\$ 1.3$ trillion spending bill, causing the administration to add an addendum to its 2019 budget and seemingly save science and innovation from painful budget cuts. 69

Although deep cuts to major research agencies, such as the NIH and NSF, have been rescinded following the last-minute budget addendum, some programs remain on the chopping block. The EPA is facing some of the most drastic budget cuts, $\$ 2.1$ billion or roughly $25.6 \%$ based on the agency's 2017 budget. ${ }^{70}$ Under this proposed budget, the administration moves to eliminate the EPA's contributions to the

64. U.S. DEP'T OF DEF., supra note 62 .

65. Stein, supra note 63.

66. Robert Pear, Congress Rejects Trump Proposals to Cut Health Research Funds, N.Y. TIMES (Sept. 11, 2017), https://www.nytimes.com/2017/09/11/us/politics/national-insti tutes-of-health-budget-trump.html; OfFICE OF MGMT. \& Budget, EFFICIENT, EFFECTIVE, ACCOUNTABLE: AN AMERICAN BUDGET (2019), https://www.whitehouse.gov/wp-content/up loads/2018/02/budget-fy2019.pdf; David Malakoff, First Take: Trump's 2019 Budget Not as Disastrous for Science as It First Appears, SCIENCE (Feb. 12, 2019), http://www.science mag.org/news/2018/02/first-take-trump-s-2019-budget-request-not-quite-disastrous-scien ce-it-first-appears.

67. Pear, supra note 66 .

68. Id.; OFFICE OF MGMT. \& BUDGET, supra note 66; Malakoff, supra note 66.

69. Marina Koren, Congress Ignores Trump's Priorities for Science Funding, ATLANTIC (Mar. 23, 2018), https://www.theatlantic.com/science/archive/2018/03/trumpscience-budget/556229/.

70. Matt Hourihan \& David Parkes, Am. Ass'N for the Advancement of Sci., Guide to the PRESIDENT's Budget: REsEARCH AND DEVELOPMENT FY 2019 at 52 (2018), https://mcmprodaaas.s3.amazonaws.com/s3fs-public/AAAS\%20R\%26D\%20Report\%20FY 19\%20Final.pdf?4LWpHID69_hmH5PvKJ_RnkFtYNciOFhM. 
Global Change Research Program and to eliminate several activities including climate change research. ${ }^{71}$ Further, both the Greenhouse Reporting Program and the Greenhouse Gas Inventory Program would operate at substantially reduced levels. ${ }^{72}$ Similarly, the National Institute of Standards and Technology ${ }^{73}$ faces a $\$ 117$ million budget cut, which will reduce its budget $16.9 \%$ based on 2017 budget levels, ${ }^{74}$ and the Department of Energy's Advance Research Project Agency-Energy is slated for complete elimination. ${ }^{75}$ These research and development budget cuts, among others, not only have a direct deterrent effect on innovation due to a reduction of resources, but also have an indirect effect of deterring innovation by reducing the pressure on industry to innovate.

While science and technology $R \& D$ budgets remain relatively intact despite the White House's efforts to cut and eliminate programs, can Congress continue to add funding back to the president's budget when members are facing reelection? Given that the federal budget deficit for fiscal year 2019 will reach $\$ 985$ billion (18\% greater than the previous year), ${ }^{76}$ how long can they hold the line? Although budget deficits can add to economic growth, continued budget deficits can result in inflation, and an unmanageable national debt, which can in turn stunt economic growth and result in an economic crisis.

\section{The Role OF THE USPTO IN PROMOTING INNOVATION}

While the future of innovation in the United States largely remains under a shadow of debate, a potential ray of light exists with the United States Patent and Trademark Office (USPTO). Although the supremacy of the United States intellectual property system has waned in recent

71. $I d$.

72. $I d$.

73. The National Institute of Standards and Technology is a part of the United States Department of Commerce and was established to promote innovation and industrial competitiveness. Innovations such as advanced nanomaterials, computer chips, and the smart electric power grid (among others) rely in some way on the technology, measurement, and standards provided by the National Institute of Standards and Technology. About NIST, NIST, https://www.nist.gov/about-nist (last visited Dec. 10, 2018).

74. HOURIHAN \& PARKES, supra note 70, at 40.

75. Id.

76. Kimberly Amadeo, Current U.S. Federal Budget Deficit: The Three Reasons the U.S. Deficit is out of Control, BALANCE (Jan. 17, 2019), https://www.thebalance.com /current-u-s-federal-budget-deficit-3305783. 
years, ${ }^{77}$ hope remains due to a change in leadership and a renewed agenda at the USPTO. The newly appointed Director, Andrei Iancu, promotes a stronger, more innovative future for the USPTO, and ongoing discussions about the USPTO potentially being granted agency status gives it the opportunity to take the lead in promoting innovation and bringing the United States back to its former position as the best, most innovative country in the world. ${ }^{78}$

Director Iancu plans to take steps to strengthen and enhance the reliability of the United States patent system. This plan includes initiatives to improve patent quality, more clearly defining the test for patentable subject matter, and evaluating the Patent Trials and Appeals Board (PTAB) practices in order to streamline post-grant procedures, making them more efficient and equitable for all parties. ${ }^{79}$ Improving the process of how patents are drafted and examined will result in higher quality patents being issued. This is important because the better the quality of the patent application and examination, the less likely that a particular patent will be challenged. The director has supported the development of a pilot project that would identify patent applications that could benefit from a pre-search interview. ${ }^{80}$ This would allow the examiner to obtain more clarity from the applicant and resolve issues prior to performing the full patent examination. ${ }^{81}$ This should result in a more effective prior art search, reduce the time the application is under review, and produce an issued patent that is easily defendable. This pilot project can prove to be especially beneficial to the small inventor, who cannot afford the expense of post-grant PTAB procedures and infringement litigation.

77. Cong. Budget OfFice, supra note 54, at 32-33. The influence of the intellectual property system, more specifically the patent system, weighs heavily on the United States' innovation and growth potential. "[P]roblems with the patent system-including too many low-quality patents, the considerable length of time required to process patent applications, and the rising cost of patent infringement litigation-may have weakened the linkage between patenting and innovation." Id. at 33 .

78. Andrei Inacu, Dir., U.S. Patent \& Trademark Office, Statement Before the House Committee of the Judiciary: Oversight of the U.S. Patent and Trademark Office (May 22, 2018), https://www.uspto.gov/about-us/news-updates/statement-director-andrei-iancu-com mittee-judiciary-0. While the United States once had the strongest intellectual property system in the world, since 2016, the United States has fallen to tenth in a worldwide analysis for net impact on global innovation. Stephen J. Ezell ET AL., INFo. TeCh. \& INNOVATION FOUND., CONTRIBUTORS AND DETRACTORS: RANKING COUNTRIES' IMPACT ON GLOBAL INNOVATION 1 (2016), http://www2.itif.org/2016-contributors-and-detractors.pdf ?_ga=2.174823970.1459542855.1544558624-1133091884.1544470606.

79. Inacu, supra note 78.

80. Id.

81. $I d$. 
The director has also expressed the need to provide greater clarity and guidance on patentable subject matter eligibility. The Supreme Court of the United States issued a series of decisions between 2010 and 2014 applying 35 U.S.C. $\S 101^{82}$ to business, high-tech, and biotech inventions. ${ }^{83}$ The Court found that the patents were invalid, determining that the inventions were based on abstract ideas, laws of nature, or facts of nature, which traditionally have been excluded as patentable subject matter. ${ }^{84}$ These decisions have generated substantial debate in the intellectual property legal community over what subject matter can be patented. ${ }^{85}$ Following "these decisions-as well as numerous Federal Circuit decisions applying what is now known as the Mayo-Alice framework-the USPTO" have guided both examiners and the public on how to best navigate the patent eligibility legal landscape. ${ }^{86}$ Many stakeholders feel that courts have restricted subject matter eligibility in such a way that it deters innovation in natural sciences. ${ }^{87}$ The director has stated a concern that the current state of subject matter eligibility weakens the robustness of the United States intellectual property system, specifically in the areas of artificial intelligence and DNA processing. ${ }^{88}$ As a result, Iancu has expressed a willingness to work with Congress to reform Section 101 should

82. 35 U.S.C. $§ 101$ (2018). Section 101 addresses the subject matter eligibility requirement for patent applications. Id. ("Whoever invents or discovers any new and useful process, machine, manufacture, or composition of matter, or any new and useful improvement thereof, may obtain a patent therefor, subject to the conditions and requirements of this title."). Following the decisions in Mayo Collaborative Services $v$. Prometheus Laboratories, Inc., 566 U.S. 66 (2012), and Alice Corp. v. CLS Bank International, 573 U.S. 208 (2014), there has been increased debate concerning what inventions are considered patentable under law.

83. Alice Corp., 573 U.S. 208 (relating to computer software); Ass'n for Molecular Pathology v. Myriad Genetics, Inc., 569 U.S. 576 (2013) (addressing human genes); Mayo Collaborative Servs., 566 U.S. 66 (considering a method of medical diagnosis); Bilski v. Kappos, 561 U.S. 593 (2010) (pertaining to business methods).

84. Alice Corp., 573 U.S. at 212; Ass'n for Molecular Pathology, 569 U.S. at 589; Mayo Collaborative Servs., 566 U.S. at 70; Bilski, 561 U.S. at 601-02.

85. Inacu, supra note 78.

86. $I d$.

87. For example, the discovery of Artemisinin, which has been used to treat malaria, won the Chinese biochemist who discovered it a Nobel Prize, but is not patentable in the United States. See Daniel Cole, Why Removing Section 101 Won't Be Enough, IP WATCHDOG (Aug. 7, 2016), https://www.ipwatchdog.com/2016/08/07/removing-section-101wont-be-enough/id=71693/.

88. Gene Quinn, Director Iancu Worries Current State of Section 101 "Weakens the Robustness of Our IP System," IP WATCHDOG (May 15, 2018), https://www.ip watchdog.com/2018/05/15/iancu-part-2/id=97191/. 
Congress show a willingness to do so. ${ }^{89}$ However, this is a contentious issue. There are those that believe that the Court was correct in tightening up the patent eligibility standard as too many vague and overbroad patents have been issued, which later results in protracted litigation. It is unlikely that Congress will take on such a controversial legislation when the various stakeholders are so deeply divided on the issue.

Another controversial area that the director is addressing is the PTAB post-grant proceedings that became effective with the passage of the America Invents Act (AIA). ${ }^{90}$ These procedures were designed to improve the quality and integrity of the patents that are granted by providing a process to review invalid patents mistakenly issued before they result in costly litigation. However, stakeholders have strong opinions about their effectiveness, and some suggest that they contribute to the decline in the U.S. patent system rankings. ${ }^{91}$ The director is currently taking steps to assess potential improvements to the trial standards and processes and ensure that the PTAB applies the same standards to their proceedings as are applied to patent litigation in the district courts. ${ }^{92}$

The USPTO is essentially a regulatory body. As such, it is subject to the requirements of Executive Order 13771. While the USPTO has established a Working Group on Regulatory Reform, ${ }^{93}$ it has a herculean task before it. It must cautiously balance the need to make improvements to the patent system while at the same time complying with the mandates of the Order. However, the House Budget Committee has recently discussed the possibility of establishing the USPTO as an independent agency. ${ }^{94}$ Such a move could remove the USPTO from the requirements of Executive Order 13771. The Order

89. Gene Quinn, Iancu: "It Is Unclear What Is Patentable and What Is Not, and That Can Depress Innovation," IP WATchDog (May 22, 2018), http://www.ipwatchdog.com/ 2018/05/22/iancu-unclear-patentable-depress-innovation/id=97559/ ("So, if this Committee, or Congress in general, is interested in tackling 101, we would be very happy to work with the Committee on those issues.").

90. Inacu, supra note 78; see also Pub. L. No. 112-29, 125 Stat. 284 (2011).

91. Inacu, supra note 78 .

92. Id.

93. The USPTO Working Group on Regulatory Reform is led by Nicolas Oettinger and was formed to identify regulations that can be revised, improvised, streamlined, or removed as a result of the Trump Administration's 2-for-1 regulation reform order. Working Group on Regulatory Reform, USPTO, https://www.uspto.gov/about-us/workinggroup-regulatory-reform (last visited Dec. 10, 2018).

94. Gene Quinn, House Republicans Propose USPTO as an Independent Agency, IP WATCHDOG (Sept. 29, 2017), http://www.ipwatchdog.com/2017/09/29/house-republicansuspto-independent-agency/id $=88670 /$. 
only applies to "agencies subject to regulatory review requirements [under] Executive Order 12866," which means independent agencies are exempt, though strongly encouraged to comply. ${ }^{95}$ Independent agencies are creations of Congress and are not subject to control or influence by the executive branch. ${ }^{96}$ Therefore, whether the USPTO will remain subject to the administration's deregulation agenda could come in question. Perhaps a more important benefit of achieving agency status would be for the new agency to expand from its traditional intellectual property control function, and take more of a leadership role in promoting innovation.

\section{THE EFFECT OF ISOLATIONIST TENDENCIES ON INNOVATION}

Under the banner "America First," the Trump Administration has taken actions that have increasingly isolated the United States from the global economy. Two areas that are facing increased regulatory enforcement are foreign investment in American companies and immigration. Each may have a profound effect on innovation.

Since taking office, President Trump has prevented two significant business combinations through the Council for Foreign Investment in the United States (CFIUS). ${ }^{97}$ First, President Trump stopped a proposed $\$ 1.3$ billion acquisition of Lattice Semiconductor Corporation

95. Executive Order 13777 only applies to the following agencies: Department of Agriculture, Department of Commerce, Department of Defense, Department of Education, Department of Energy, Department of Health \& Human Services, Department of Homeland Security, Department of Housing \& Urban Development, Department of the Interior, Department of Justice, Department of Labor, Department of State, Department of Transportation, Department of the Treasury, Department of Veterans Affairs, the Environmental Protection Agency, and the National Aeronautics and Space Administration. Memorandum from Dominic J. Mancini, supra note 28.

96. Charles N. Steele \& Jeffrey H. Bowman, The Constitutionality of Independent Regulatory Agencies Under the Necessary and Proper Clause: The Case of the Federal Election Commission, 4 YALE J. ON REG. 363, 365-66 (1987).

97. "CFIUS is an interagency committee authorized to review certain transactions" that could result in control of a United States business by a foreign person "in order to determine the effect of such transactions on the national security of the United States." The Committee on Foreign Investment in the United States (CFIUS), U.S. DEP'T TREASURY, https://home.treasury.gov/policy-issues/international/the-committee-onforeign-investme nt-in-the-united-states-cfius (last visited Dec. 10, 2018). While the president does not sit on CFIUS, he has control over its membership. Perloms Coie, CFIUS: President-Elect Trump's Potential Big Stick for China and Foreign Trade, PERKINS COIE (Jan 19, 2017), https://www.perkinscoie.com/en/news-insights/cfius-trumps-potential-big-stick-for-china-and-foreign-trade.html. CFIUS consists of cabinet members, though the president may designate other senior officials as members by executive order. $I d$. Further, the president has the authority to block a transaction in his discretion. $I d$. 
by Canyon Bridge Capital Partners (a United States-headquartered private equity firm reportedly funded by the Chinese government). ${ }^{98}$ Second, he intervened in Broadcom Limited's \$117 billion takeover of Qualcomm Incorporated. ${ }^{99}$ It is believed that the president opposed the Broadcom-Qualcomm deal because of concern that it could curtail United States investments in chip and wireless technology and allow Huawei Technologies, a Chinese company, to gain market superiority. ${ }^{100}$ Regardless of the reasons behind blocking each transaction, there is a marked increase in presidential intervention. ${ }^{101}$ Additionally, there is proposed legislation, the Foreign Investment Risk Review Modernization Act of 2017 (FIRRMA) ${ }^{102}$ that aims to further strengthen CFIUS and expand the committee's scope of review. 103 Although FIRRMA is facing opposition in Congress, the enactment of such legislation would likely increase the ability of the administration to intervene in foreign sales which could have an effect on innovation in the United States.

Ironically, there exists an apparent disjunction between Trump's desire to protect the strength of the United States economy and his existing immigration policies. The White House's current stance on immigration promotes a reversal of the brain drain often associated with the increased technological development of the 1990s and 2000s. Of the engineering and technology companies established in Silicon Valley between 1995 and 2006, 50\% were founded by immigrants. ${ }^{104}$ Two notable examples are Elon Musk, founder of SpaceX and Tesla, and

98. Jinsong Zhang et al., Trump Blocks His First CFIUS Deal-What Can We Learn from It?, KING \& WOOD MALLESONS (Oct. 11, 2017), https://www.kwm.com/en/us/knowled ge/insights/trump-blocks-his-first-cfius-deal-what-can-we-learn-from-it-20171011; Farhad Jalinous et al., CFIUS: President Trump Blocks Acquisition of Lattice Semiconductor by Canyon Bridge, WHITE \& CASE (Sept. 13, 2017), https://www.whitecase.com/publications/ alert/cfius-president-trump-blocks-acquisition-lattice-semiconductor-canyon-bridge.

99. David McLaughlin \& Kristy Westgard, All About CFIUS, Trump's Watchdog on China Dealmaking: Quick Take, BLOOMBERG (Mar. 23, 2018), https://www.bloomberg.com /news/articles/2018-03-23/all-about-cfius-trump-s-watchdog-on-china-dealmaking-quick take.

100. How Fear of Huawei Killed \$117 Billion Broadcom Deal, Bloomberg (Mar. 12, 2018) https://www.bloomberg.com/news/articles/2018-03-13/how-china-s-huaweikilled117-billion-broadcom-deal-quicktake.

101. Since CFIUS was originally passed in 1988 , there have been only five recorded presidential blocks. Jalinous et al., supra note 98. Of these presidential blocks, two have occurred under the Trump Administration. Id.

102. H.R. 4311, 115th Cong. (2017).

103. Id.

104. Janice D. Villiers, Closing the Borders: Reverse Brain Drain and the Need for Immigration Reform, 55 WAYNE L. REV. 1877, 1877-78 (2009). 
Google cofounder Sergey Brin. ${ }^{105}$ Further, during the same time period, "one in every four patents in the World Intellectual Property Organization listed a foreign national residing in the United States as the inventor." 106 From the early 1990s until the mid-2000s, the United States was reaping the innovative rewards of a mass brain gain as the best and the brightest from across the world came to the United States. However, in the last decade researchers have found that there is a notable change resulting in a brain drain for the first time in United States history. ${ }^{107}$ Many of the highly skilled, legal immigrants of the United States have decided to return to their home countries due to the stringent immigration laws of the United States, taking with them their "skills and entrepreneurial spirit" at the expense of United States' innovation. ${ }^{108}$

While the brain drain pattern has been present since the mid-2000s, it is likely that the immigration policies of the administration will further exacerbate this trend and result in a substantial loss of technological talent. Through a number of executive orders and agency memorandum, the administration has started tightening visa requirements. ${ }^{109}$ The $\mathrm{H}-1 \mathrm{~B}$ visa in particular faces increased scrutiny. ${ }^{110}$ Evidence suggests that for every H-1B worker, five jobs are created.111 In fact, much of the negative impact of increased immigration scrutiny on innovation is already surfacing. The United States faces a steep decline in the presence of tech "unicorns," dropping from $75 \%$ in 2013 to $41 \%$ today. ${ }^{112}$ To make matters worse, China is increasing its share of tech "unicorns," now home to $36 \%$ of unicorns in comparison to $12 \%$ in 2014. ${ }^{113}$ The administration needs to take into consideration the longterm effects its immigration and isolationist policies have on innovation.

105. Sheng, supra note 4.

106. Villiers, supra note 104 , at 1878

107. Id. at 1882 .

108. Id. at 1883 .

109. Sheng, supra note 4.

110. A H-1B visa allows nonimmigrant aliens to work in specialty occupations. $H-1 B$ Program, U.S. DEP’T LAB., https://www.dol.gov/whd/immigration/h1b.htm (last visited Feb. 24, 2019).

111. Sheng, supra note 4.

112. Id.

113. Id. 


\section{CONCLUSION}

When the topic of government regulatory policy is discussed, most immediately think of the burdens that regulations put on businesses and their effect on corporate profitability. For those, the appeal of the political rhetoric surrounding deregulation and the " 2 -for- 1 " order are appealing. However, our government institutions and economic system are much more complex than that. While regulatory reform policies can serve to improve the efficiency of markets in the delivery of goods and services, it can also both encourage and discourage innovation. It is clear that the pursuit of short-term profitability at the expense of investment in innovation and the adoption of new technology can lead to the demise of a corporation. The importance innovation has to the American economy and the recent decline in the nation's innovation leadership must be acknowledged. It is imperative that policy makers adopt a regulatory agenda that includes a more comprehensive strategy that focuses not on the number of regulations, but on improving the national environment for innovation. 